\title{
EVALUASI PROGRAM KELAS RISET DI MAN 2 PONOROGO PADA MASA PANDEMI COVID-I9
}

\author{
Reny Refitaningsih Peby Ria \\ Universitas Negeri Yogyakarta \\ Cut Maisarah \\ Universitas Negeri Yogyakarta
}

\section{Sudiyatno}

Universitas Negeri Yogyakarta

\author{
Nur Hidayanto Pancoro Setyo \\ Putro \\ Universitas Negeri Yogyakarta
}

\section{Alamat Korespondensi}

renyrefitaningsih.2020@student.uny.ac.id

\begin{abstract}
This study aims to evaluate the implementatiton of the research class program at MAN 2 Ponorogo. The CIPP model was adopted as the evaluation model in this study. The sources of data information are vice principals of curriculum, vice principals of student, teacher of research, and students. The data in this study were collected through observation, interviews, questionnaires, and documentation. The findings showed that: (I) context, research class programs were very much needed to support the policy of establishing research schools; (2) input, the school had established a research class student selection system, and the provision of infrastructure to support program implementation; (3) the process, the research class service program ran smoothly even-though there were obstacles that hindered the running of the program (4) the implementation of the research class program had been achieved in accordance with the program's achievement criteria.
\end{abstract}

Keywords: Research Class, Program Evaluation, Cipp Model

\section{PENDAhuluan}

Era revolusi industri 4.0 telah mendorong adanya terobosan-terobosan baru di bidang ilmu pengetahuan dan teknologi seperti pemanfaatan artificial intelligence dalam pelayanan digital, jaringan data 5G, autonomous car, extended reality dan lainlain. Kemajuan ilmu pengetahuan dan teknologi tersebut dipengaruhi oleh kebutuhan manusia yang semakin kompleks di era industri 4.0. Kehidupan era industri 4.0 telah membawa perubahan terhadap pengembangan sumber daya manusia dan perilaku konsumen yang berpengaruh pada pola hidup manusia yang menuntut adanya efektivitas dan efisiensi dalam menjalani kegiatan sehari-hari (Sima $\mathrm{dkk}, 2020$ ). Manusia menggunakan akal dan ilmu pengetahuan yang dimilikinya untuk menciptakan teknologi agar dapat memecahkan masalah seperti penggunaan mesin untuk mempermudah pekerjaan serta pemanfaatan internet untuk mempermudah komunikasi dan pertukaran arus informasi tanpa pengaruh batasan jarak dan waktu. Melihat kemajuan ilmu pengetahuan dan teknologi tersebut, hal itu tentu tidak lepas dari peranan kegiatan riset dan inovasi yang dilakukan oleh manusia. Hal ini dikarenakan, inovasi membutuhkan pengetahuan baru untuk memenuhi kebutuhan masyarakat yang diikuti oleh pengembangan teknologi, dimana pengetahuan baru ini diperoleh dari penemuan selama pelaksanaan riset (Ekolu, 2018).

Riset atau penelitian didefinisikan sebagai kegiatan untuk memecahkan berbagai permasalahan yang ada di lingkungan sekitar manusia dan dijadikan sebagai motor pengerak yang menghasilkan ilmu pengetahuan (Suryani \& Hendryadi, 20l6). Di satu sisi, Alfanika (2018) menyatakan bahwa riset dapat diartikan sebagai suatu kegiatan yang dilakukan dengan tujuan untuk mencari suatu kebenaran atau memecahkan masalah yang ada di lingkungan sekitar. Di sisi lain, Naidoo (20II) mengatakan bahwa riset merupakan sebuah penyelidikan yang dilakukan secara sistematis terhadap alam dan masyarakat untuk memvalidasi dan menyempurnakan pengetahuan yang ada dan untuk menghasilkan pengetahuan yang baru. Hasil riset yang dilakukan dapat memberikan manfaat bagi objek riset yang dikaji, pengembangan ilmu yang diterapkan dalam riset dan bermanfaat bagi kemaslahatan masyarakat (Firdaus \& Zamzam, 2018). Melihat kebermanfaat riset, maka pemerintah Indonesia perlu mendorong warga negaranya untuk aktif dalam melakukan kegiatan riset dan pengembangan inovasi yang berkelanjutan untuk memujudkan bangsa yang berdaya saing. Akan tetapi, dalam mewujudkan hal tersebut, pemerintah Indonesia masih menghadapi 
kondisi lemahnya:

“I) kapasistas dan kompetenesi riset, 2) kemampuan pengembangan menuju proses penciptaan berbasis iptek, 3) jaringan kelembagaan dan peneliti di ranah lokal, regional, dan global, 4) produktivitas dan relevansi litbang nasional untuk menjawab kebutuhan teknologi masyarakat, dan 5) pendayagunaan riset dan pengembangan nasional untuk penciptaan nilai tambah pada sumberdaya alam dan produk inovasi nasional dalam rangka meningkatkan daya saing ekonomi (Kementerian Riset, Teknologi, dan Pendidikan Tinggi, 20I7).

Sehubungan dengan kondisi di atas, kendala biaya dan fasilitas riset yang tidak mendukung juga menjadi faktor tidak berkembangnya pelaksanaan riset. Maka dari itu untuk mendorong peningkatan kontribusi riset, pemerintah Indonesia telah menerbitkan suatu kebijakan. Salah satu kebijakan yang dirilis di bidang pendidikan yaitu Surat Keputusan Direktur Jenderal Pendidikan Islam Nomor 6757 Tahun 2020 tentang Penetapan Madrasah Penyelenggara Riset. Penyelenggaraan riset di madrasah ini dilakukan dengan memberikan pembelajaran berbasis riset kepada para siswa. Menurut Slameto (2015) pembelajaran berbasis riset merupakan pembelajaran yang menuntut siswa untuk dapat menemukan, mengeksplorasi pengetahuan untuk menyelesaikan masalah yang dihadapi dan kemudian menguji kebenaran pengetahuan tersebut.

Tujuan dari pembelajaran berbasis riset, yaitu: a) meningkatkan kebermanfaatan mata pelajaran riset yang lebih bersifat konstekstual melalui pemaparan hasil-hasil penelitian b) memperkuat kemampuan berpikir siswa sebagai peneliti, c) melengkapi pembelajaran melalui internalisasi nilai penelitian, praktik, dan etika penelitian dengan cara melibatkan penelitian, d) meningkatkan mutu penelitian dan melibatkan siswa dalam kegiatan penelitian, e) meningkatkan pemahaman siswa mengenai perkembangan suatu ilmu melalui penelitian yang berkelanjutan, dan f) meningkatkan pemahaman tentang peran penelitian dalam inovasi sehingga mendorong siswa untuk selalu berpikir kreatif di masa depan (Haryati \& Firmadani, 20l8). Selain itu, Yulhenderi, Syofyan, \& Afridona (2018) menyatakan bahwa pembelajaran riset bertujuan untuk menciptakan proses pembelajaran yang mengarah pada kegiatan analisis, sintesis, dan evaluasi serta dapat meningkatkan kemampuan siswa dan guru dalam hal asimilasi penerapan ilmu. Untuk mencapai keberhasilan pelaksanaan pembelajaran berbasis riset di sekolah, ada delapan strategi yang dapat diterapkan pada model pembelajaran berbasis riset ini, yaitu: (I) memperkaya bahan ajar dengan hasil penelitian guru; (2) menggunakan temuantemuan penelitian mutakhir dan melacak sejarah; (3) memperkaya kegiatan pembelajaran dengan isu-isu penelitian kontemporer; (4) mengajarkan materi metodologi penelitian dalam proses pembelajaran; (5) memperkaya proses pembelajaran dengan kegiatan penelitian dalam skala kecil; (6) memperkaya proses pembelajaran dengan melibatkan siswa dalam kegiatan penelitian; (7) memperkaya proses pembelajaran dengan mendorong siswa agar merasa menjadi bagian dari kegiatan riset; dan (8) memperkaya proses pembelajaran dengan nilai-nilai yang harus dimiliki oleh peneliti (Umar dkk, 20ll). Akan tetapi, meskipun terdapat beberapa strategi di atas, pada praktiknya terdapat beberapa faktor yang mempengaruhi proses pembelajaran riset, sehingga guru perlu memperhatikan faktor-faktor tersebut. Menurut Haryati (2020) ada dua faktor yang mempengaruhi proses pembelajaran riset antara lain: (a) faktor intern, faktor-faktor yang mempengaruhi proses dan hasil belajar yang berasal dari siswa yang meliputi kondisi fisiologis dan psikologi; (b) faktor intern, faktor-faktor yang mempengaruhi proses dan hasil belajar siswa yang berasal dari luar diri siswa yang meliputi faktor lingkungan dan faktor instrumental. Selain itu, metode mengajar guru juga menjadi faktor yang berpengaruh terhadap proses pembelajaran, seperti kesesuaian metode mengajar, latihan dan penerapan pengetahuan, penggunaan alat peraga, penggunaan kegiatan ko-kurikuler dalam pengajaran mata pelajaran tertentu (Pandhi, 202I).

Terlebih pada kondisi pandemi COVID-19, kebijakan yang diambil oleh Pemerintah Indonesia untuk meminimalisir penyebaran COVID-19 dengan meniadakan pembelajaran secara luring, sehingga pemerintah harus menghadirkan alternatif proses pendidikan untuk siswa (Abidah dkk, 2020). Alternatif proses pendidikan yang ditetapkan oleh pemerintah adalah dengan melakukan pembelajaran daring, sehingga perubahan proses pendidikan ini tentu berpengaruh terhadap proses pembelajaran di sekolah. Hal inilah yang dirasakan oleh MAN 2 Ponorogo sebagai salah satu madrasah yang ditunjuk untuk menyelenggarakan program riset di madrasah. Adanya pandemi COVID-19 mengakibatkan implementasi program kelas riset menjadi terkendala dan kurang optimal karena pembelajaran dilakukan 
secara daring. Pernyataan tersebut, didukung dari hasil observasi dan wawancara evaluator dengan guru mata pelajaran riset di MAN 2 Ponorogo. Beliau menyatakan bahwa guru memiliki kendala untuk membimbing siswa secara intensif karena pertemuan pembelajaran hanya dilakukan secara daring. Padahal siswa masih memerlukan bimbingan untuk mempelajari riset khususnya dalam mengajak siswa untuk berpikir kritis dan kreatif dalam menemukan masalah serta mengali ide untuk pemecahan permasalahan.

Selain itu, berdasarkan hasil wawancara evaluator dengan salah satu siswa kelas riset menyatakan kendala yang dihadapi siswa ketika mengikuti program kelas riset adalah adanya kendala komunikasi karena pembelajaran dilakukan secara daring. Pembelajaran secara daring menyebabkan intensitas tanya jawab terkait materi riset terbatas dan tidak leluasa seperti tatap muka. Merujuk pada kondisi di atas, maka penting untuk dilakukan evaluasi mengenai pelaksanaan program kelas riset pada masa pandemi COVID-19 guna menjawab permasalahan tersebut. Untuk menjawab permasalahan tersebut, tentu perlu dilakukan penelitian evaluasi secara komprehensif dengan menggunakan model evaluasi CIPP (Context, Input, Process, Product). Menurut Ananda \& Rafida (2017) Pengunaan model CIPP memiliki keunggulan dalam memberikan format evaluasi yang menyeleuruh pada setiap tahapan evaluasi, yaitu tahap context, input, process, product, sehingga dapat diperoleh kesimpulan dan rekomendasi secara empiris mengenai masalah tersebut.

Merujuk pada permasalahan di atas, maka rumusan masalah dalam penelitian ini adalah bagaimana konteks, input, proses, dan produk program kelas riset pada masa pandemi COVID-19? Berkaitan dengan itu, tujuan penelitian adalah untuk mengevaluasi konteks, input, proses, dan produk program kelas riset pada masa pandemi COVID-19. Hasil penelitian ini diharapkan dapat dijadikan bahan referensi terkait evaluasi program kelas riset, dan dapat digunakan oleh pihak madrasah sebagai data ilmiah dalam membuat keputusan untuk perbaikan program di masa depan, serta dapat berguna sebagai saran untuk perbaikan dalam pelaksananaan kebijakan mengenai penetapan madrasah penyelenggara riset yang dilakukan oleh Kementerian Agama Republik Indonesia.

\section{METODE PENELITIAN}

Jenis penelitian ini adalah penelitian evaluasi dengan dengan menggunakan model evaluasi CIPP. Sumber informasi data dalam penelitian ini adalah wakil kepala sekolah bagian kurikulum, wakil kepala sekolah bagian kesiswaan, guru mata pelajaran riset, dan siswa kelas riset. Pada penelitian ini ada empat aspek yang dievaluasi, yaitu I) tujuan program (konteks), 2) prosedur dalam pelaksanaan program, sumber daya manusia, sarana dan prasarana yang mendukung pelaksanaan program (input), 3) kegiatan yang dilakukan dalam program (proses), 4) ketercapaian program (produk). Sehubungan dengan itu, teknik dan instrumen pengumpulan data dilakukan dengan: a) wawancara, peneliti melakukan wawancara langsung kepada subjek penelitian terkait pelaksanaan program kelas riset. Sebelum wawancara, peneliti terlebih dahulu menyiapkan pedoman wawancara sebagai acuan, b) observasi, peneliti melakukan pengamatan terhadap pelaksanaan program kelas riset serta observasi dilakukan sebagai alat re-checking terhadap informasi yang diperoleh dari kegiatan wawancara, alat yang digunakan dalam melakukan observasi adalah rekaman video dan rekaman suara, c) kuesioner, peneliti memberikan sejumlah pertanyaan kepada respoden dengan google form untuk mengumpulkan informasi terkait kegiatan yang terdapat dalam program kelas riset, d) dokumentasi, peneliti mengumpulkan dokumen-dokumen dari informan yang berupa foto, dokumen abstrak siswa, dan dokumen hasil belajar siswa pada mata pelajaran riset.

Selanjutnya, teknik pengujian keabsahaan data untuk pedoman wawancara menggunakan triangulasi sumber dan uji dependabilitas, sementara untuk pembuktian validitas isi pedoman wawancara dan kuesioner menggunakan Aiken's V. Kemudian, teknik analisis data Teknik analisis data kualititatif digunakan untuk menganalisis data yang diperoleh dari observasi, wawancara, dan dokumentasi terkait pelaksanaan program kelas riset, mulai dari tahap evaluasi konteks, input, proses, hingga produk. Model teknik analisis data kualitatif ini menggunakan model Miles \& Huberman yang dilakukan dengan tiga tahap, yaitu mereduksi data, penyajian data, dan penarikan kesimpulan. Sementara itu, untuk teknik analisis data kuantitatif digunakan untuk menganalisis data yang diperoleh dari kuesioner terkait pelaksanaan program kelas riset yang berfokus pada tahap evaluasi proses. Untuk memperoleh data deskripsi dari kuesioner, skor jawaban responden akan dianalisis menggunakan statististik deskriptik kuantitatif dengan tabel distribusi frekuensi untuk mengetahui kecenderungan gugus data. 


\section{HASIL PENELITIAN DAN PEMBAHASAN Aspek Konteks}

Penyelenggaran progam kelas riset di MAN 2 Ponorogo dilatar belakangi adanya kebijakan dari Kementerian Agama Republik Indonesia, yaitu Surat Keputusan Direktur Jenderal Pendidikan Islam Nomor 6757 Tahun 2020 tentang Penetapan Madrasah Penyelenggara Riset. Berdasarkan surat keputusan tersebut, MAN 2 Ponorogo terpilih sebagai madsarah untuk penyelenggaraan riset bersama 403 Madrasah Aliyah lainnya di Indonesia. Untuk mendukung pemberlakuan kebijakan tersebut, MAN 2 Ponorogo menawarkan program kelas riset. Penyelenggaran program kelas riset ini bertujuan untuk mengembangkan riset bagi warga madrasah, mewadahi bakat siswa di bidang riset, serta menjadi madrasah induk riset (sister school) bagi madrasahmadrasah yang berada dibawah naungan MAN 2 Ponorogo. Sehubungan dengan itu, sasaran program ditujukan kepada siswa yang mempunyai bakat dan minat di bidang riset.

Temuan penelitian ini didukung oleh pernyataan Widayati (2010 dalam Haryati \& Firmadani, 2018) yang menyatakan bahwa tujuan pembelajaran berbasis riset, yaitu meningkatkan mutu penelitian dan melibatkan siswa dalam kegiatan penelitian, dan meningkatkan pemahaman tentang peran penelitian dalam inovasi, sehingga mendorong siswa untuk selalu berpikir kreatif di masa depan. Selain itu, tujuan program kelas riset ini juga sejalan dengan hasil penelitian Firmadani (2017) yang menyatakan bahwa pelaksanaan kelas riset in dapat dijadikan sebagai bentuk inovasi pelaksanakaan kegiatan pembelajaran yang memberikan dorongan kepada siswa agar memiliki keterampilan berpikir kritis. Untuk mewujudkan tujuan program, maka diperlukan kerjasama dan dukungan dari stakeholder (Kementerian Agama Ponorogo, pengawas madrasah, komite madrasah, kepala madrasah, guru, karyawan madrasah, masyarakat, dan praktisi pendidikan) akan memberikan pertimbangan dalam penentuan pelaksanaan kebijakan pendidikan riset di madrasah. Sebagaimana teori yang disampaikan oleh Tuhurima (2016) yang menyatakan bahwa partisipasi stakeholder diharapkan dengan suka rela memberikan kerjasama dan dukungan untuk meningkatkan kualitas penyelenggaran program kelas riset.

\section{Aspek Input}

Untuk menjaring calon siswa yang mempunyai bakat dan minat di bidang riset, madrasah telah menetapkan sistem seleksi melalui PPDB jalur prestasi, tes masuk madrasah dengan pemberian soal yang berkaitan dengan riset, pemberian angket peminatan di bidang riset, serta calon siswa diminta untuk membuat abstrak penelitian. Hasil temuan penelitian ini didukung oleh pernyataan Kompri (2017) yang menyatakan bahwa kegiatan rekrutmen siswa riset ini merupakan proses pencarian, menentukan dan menarik pelamar yang mampu untuk menjadi siswa di lembaga pendidikan (madrasah) yang bersangkutan. Berdasarkan hasil seleksi tersebut, siswa yang terpilih menjadi bagian kelas riset ada 23 siswa. Untuk program kelas riset ini dilaksanakan dalam bentuk pembelajaran berbasis riset dengan nama mata pelajaran riset. Adanya mata pelajaran riset ini berguna untuk membimbing siswa dalam menemukan, mengeskpolarasi pengetahuan untuk memyelesaikan masalah yang mereka hadapi. Dengan demikian, keguanaan pembelajaran berbasis riset ini sejalan dengan hasil penelitian Slameto (20I5) yang menyatakan bahwa pembelajaran berbasis riset menuntut siswa untuk dapat menemukan, mengeksplorasi pengetahuan untuk menyelesaikan masalah yang dihadapi dan kemudian menguji kebenaran pengetahuan tersebut. Pernyataan tersebut, juga didukung oleh hasil penelitian Naidoo (20II) yang mengatakan bahwa kegiatan riset dilakukan secara sistematis terhadap alam dan masyarakat untuk memvalidasi dan menyempurnakan pengetahuan yang ada dan untuk menghasilkan pengetahuan yang baru.

Secara umum, kelas yang mendapatkan pembelajaran berbasis riset adalah $X$ MIPA $3, X$ MIPA 4, X MIPA 5, dan X MIPA 6. Akan tetapi, kelas yang difokuskan sebagai kelas riset adalah kelas $X$ MIPA 3, sehingga mereka mendapatkan materi pembelajaran riset yang lebih dominan dibandingkan kelas lainnya. Jumlah guru pembimbing program kelas riset ini ada tiga guru yang akan membimbing dan mengajarkan siswa terkait teori dan praktik kegiatan riset. Hasil temuan penelitian ini didukung oleh penelitian Slameto (2015) yang menyatakan bahwa guru memiliki peran penting dalam memonitor dan memastikan siswa memperoleh pemahaman yang benar tentang materi maupun prosedur pembelajaran berbasis riset, apabila siswa mengalami kesulitan guru dapat memberikan pertolongan dengan pemberian solusi terhadap permasalahan yang dihadapi siswa. Selain adanya guru pembimbing, madrasah juga memfasilitasi sarana dan prasarana yang mendukung pelaksanaan 
program kelas riset di MAN 2 Ponorogo, seperti laboratorium fisika, laboratorium biologi, dan laboratorium kimia yang bekerja sama dengan Kimia Farma Ponorogo dan mengandeng laboratorium kimia Universitas Negeri Surakarta. Temuan penelitian ini senada dengan ungkapan Indrawan (2015) bahwa adanya pengadaan dan pendayagunaan sarana dan prasarana tersebut, tentu akan mendukung suksesmya proses pembelajaran riset, sehingga dapat mencapai tujuan pendidikan secara efektif dan efisien. Pernyataan tersebut diperkuat oleh Haryati (2020) bahwa sarana dan prasarana merupakan salah satu faktor ektern yang mempengaruhi proses dan hasil belajar siswa.

\section{Aspek Proses}

Proses pembelajaran program kelas riset dilakukan secara daring dengan menggunakan WhatsApp Group (WAG), meskipun dilakukan secara daring hal tersebut tidak menyurutkan antusiasme partisipasi siswa dalam mengikuti pembelajaran, $90 \%$ siswa berpartisipasi dalam mengikuti pembelajaran dan selebihnya tidak dapat menghadiri pembelajaran dikarenakan izin ataupun sakit. Pembelajaran berbasis riset ini dilaksanakan selama 2 jam pelajaran perminggu. Berkaitan dengan itu, Kompetensi Dasar (KD) pengetahuan yang diajarkan meliputi siklus penelitian, masalah penelitian, judul penelitian, hipotesis penelitian dan pembuatan abstrak penelitian, sementara untuk KD keterampilan, yaitu siswa diharapkan dapat menentukan juduk penelitian, membangun hipotesis penelitian, dan membuat abstrak ide penelitian. Adanya pembelajaran berbasis riset ini bertujuan untuk menciptakan proses berpikir kritis siswa dalam menemukan masalah di lingkungan sekitarnya dan menawarkan solusi dan inovasi terhadap permasalahan tersebut. Hasil temuan penelitian ini sejalan dengan pendapat Alfanika (2018) yang menyatakan bahwa kegiatan riset dilakukan dengan tujuan untuk mencari suatu kebemaran atau memecahkan masalah yang ada. Sistem belajar yang dilakukan adalah siswa dibagi menjadi tim, kemudian diminta untuk menyusun abstrak penelitian berdasarkan permasalahan yang ditemukan.

Akan tetapi, pada saat pembelajaran daring ini guru mengalami hambatan dalam membimbing siswa untuk merumuskan masalah dan mengali ide terkait permasalahan yang ada di lingkungan sekitar mereka, terlebih membimbing siswa yang baru mempelajari riset. Selain itu, ada faktor pendukung dalam pelaksanaan pembelajaran ini, yaitu bervariasinya permasalahan yang ada di lingkungan sekitar siswa. Dengan adanya permasalahan tersebut, dapat memacu siswa untuk berpikir kritis dalam memberikan pemecahan masalah. Sehubungan dengan pelaksanaan kegiatan program kelas riset yang telah di sampaikan oleh guru. Berikut ini akan disajikan respon siswa terhadap kegiatan yang dilakukan dalam program kelas riset di MAN 2 Ponorogo.

Tabel I. Respon Siswa

\begin{tabular}{|c|c|c|c|}
\hline No & Pernyataan & Kategori & Persentase \\
\hline I & $\begin{array}{l}\text { Teknis sosialisasi } \\
\text { program kelas riset di } \\
\text { MAN } 2 \text { Ponorogo }\end{array}$ & Baik & $56,5 \%$ \\
\hline 2 & $\begin{array}{l}\text { Tingkat kesesuaian } \\
\text { metode pembelajaran } \\
\text { yang diterapkan guru } \\
\text { ketika proses } \\
\text { pembelajaran riset }\end{array}$ & $\begin{array}{l}\text { Sesuai } \\
\text { Sangat } \\
\text { Sesuai }\end{array}$ & $\begin{array}{l}30,4 \% \\
30.4 \%\end{array}$ \\
\hline 3 & $\begin{array}{l}\text { Tingkat kesesuaian } \\
\text { alokasi waktu proses } \\
\text { pembelajaran riset }\end{array}$ & Sesuai & $34,8 \%$ \\
\hline 4 & $\begin{array}{l}\text { Proses pembelajaran } \\
\text { riset }\end{array}$ & Efisien & $39,1 \%$ \\
\hline 5 & $\begin{array}{l}\text { Kemampuan membuat } \\
\text { rumusan masalah } \\
\text { berdasarkan observasi di } \\
\text { lingkungan sekitar }\end{array}$ & Setuju & $52,2 \%$ \\
\hline 6 & $\begin{array}{l}\text { Kemampuan menemukan } \\
\text { solusi terhadap } \\
\text { permasalahan yang } \\
\text { terjadi di lingkungan } \\
\text { sekitar }\end{array}$ & Setuju & $34,8 \%$ \\
\hline 7 & $\begin{array}{l}\text { Pelayanan bimbingan } \\
\text { yang diberikan guru } \\
\text { ketika proses } \\
\text { pembelajaran riset }\end{array}$ & Baik & $52,2 \%$ \\
\hline 8 & $\begin{array}{l}\text { Manfaat pelaksanaan } \\
\text { program MAN } 2 \\
\text { Ponorogo }\end{array}$ & Sangat Baik & $47,8 \%$ \\
\hline 9 & $\begin{array}{l}\text { Hambatan ketika } \\
\text { mengikuti program kelas } \\
\text { riset di MAN } 2 \\
\text { Ponorogo }\end{array}$ & Ada & $65,2 \%$ \\
\hline 10 & $\begin{array}{l}\text { Faktor pendukung } \\
\text { program kelas riset di } \\
\text { MAN } 2 \text { Ponorogo }\end{array}$ & Ada & $95,7 \%$ \\
\hline II & $\begin{array}{l}\text { Pelaksanaan program } \\
\text { kelas riset di MAN } 2 \\
\text { Ponorogo untuk ke } \\
\text { depannya }\end{array}$ & Ada & $91,3 \%$ \\
\hline
\end{tabular}

Respon terhadap nomor 9 adalah mayoritas siswa menyatakan bahwa hambatan yang dihadapi ketika mengikuti program kelas riset, yaitu belum bisa memahami materi pelajaran riset karena pembelajaran dilakukan secara daring, sehingga 
kurang leluasa untuk belajar pelajaran riset. Selain itu, ada hambatan yang dihadapi siswa karena masih mengalami kesulitan untuk mencari masalah di lingkungan sekitar dan menemukan ide untuk pemecahan masalah, serta adanya rasa malas dalam diri siswa ketika hendak melakukan observasi lapangan dan mengerjakan tugas mata pelajaran riset. Respon terhadap nomor 10 adalah mayoritas siswa menyampaikan bahwa faktor pendukung pelaksanaan progam kelas riset adanya bimbingan dari guru, sarana dan prasarana yang disediakan oleh madrasah, serta masalah yang ada di lingkungan sekitar siswa yang dapat dijadikan ide untuk riset. Respon terhadap nomor II adalah harapan mayoritas siswa untuk pelaksanaan program kelas riset ke depannya adalah pembelajaran dapat dilakukan secara luring untuk mengurangi perbedaan persepsi terkait pembelajaran riset, proses pembelajaran diperbanyak kegiatan praktik untuk mengasah keterampilan siswa dalam melakukan kegiatan riset. Selain itu, guru perlu menerapkan metode pembelajaran yang disesuaikan dengan karakteristik siswa, agar siswa dapat memahami materi yang diajarkan.

Merujuk pada temuan penelitian di atas, maka faktor penghambat dan faktor pendukung pelaksanaan program kelas riset tidak lepas dari faktor-faktor yang mempengaruhi proses belajar siswa. Untuk meminimalisir hasil belajar yang rendah, maka guru perlu mengetahui faktor-faktor yang mempengaruhi proses belajar siswa (Suzana \& Jayanto, 202I). Ada dua faktor yang mempengaruhi proses pembelajaran riset antara lain: (I) faktor intern, faktor-faktor yang mempengaruhi proses dan hasil belajar yang berasal dari siswa yang meliputi kondisi fisiologis dan psikologi (Suzana \& Jayanto, 202I); (2) faktor intern, faktor-faktor yang mempengaruhi proses dan hasil belajar siswa yang berasal dari luar diri siswa yang meliputi faktor lingkungan dan faktor instrumental (Haryati, 2020).

\section{Aspek Produk}

Kriteria ketercapaian program kelas riset yang ditetapkan oleh MAN 2 Ponorogo adalah siswa mampu membuat karya dan diikutkan dalam perlombaan di bidang riset dan diharapkan mendapat juara di perlombaan tersebut. Hal ini dapat dilihat dari adanya siswa kelas riset yang berpartisipasi dan memenangkan lomba riset, seperti Wilda Aulia Zakiyyatus Sa'adah dan Risa Alvia Zahara yang lolos tahap presentasi pada lomba MYRES (Madrasah Young Research Super Camp) tahun 2020 yang diadakan oleh Kementerian Agama Islam Republik Indonesia pada bidang kategori Matematika, Sains, dan Pengembangan Teknologi. Selain itu, prestasi yang membanggakan juga diraih oleh lqbal Rizki Sucahyo mendapatkan juara I pada lomba Operation Innovatin Challenge yang diselenggarakan oleh Manajemen FBE Universitas Surabaya pada tahun 2021.

Di samping itu, hasil output dari program kelas riset juga dapat dilihat dari karya abstrak siswa dan hasil belajar siswa pada mata pelajaran riset. Ratarata hasil belajar siswa untuk kompetensi pengetahuan sebesar 86 dan rata-rata untuk kompetensi keterampilan sebesar 86. Artinya, ratarata hasil belajar yang diperoleh siswa telah melampaui KKM > 75. Hasil temuan penelitian ini didukung oleh penelitian Hardianto (2020) yang menyatakan bahwa impelementasi pembelajaran berbasis riset ini dapat meningkatkan keterampilan meneliti siswa, dan jika dilihat dari rata-rata hasil belajar, maka siswa memiliki respon yang positif terhadap pelaksanaan program kelas riset. Ketercapaian program kelas riset ini tidak lepas dari peran madrasah dan guru yang telah memberikan dukungan, sehingga siswa kelas riset dapat berpretasi di bidang riset. Temuan penelitian ini didukung penelitian Padhi (202I) yang menyatakan bahwa ketercapaian proses belajar mengajar pada kegiatan program kelas riset tidak dapat menjadi efektif tanpa adanya peran salah satu dari mereka.

\section{KESIMPULAN}

Berdasarkan analisis hasil dan pembahasan evaluasi yang dikemukakan dapat disimpulkan. Pertama, dilihat dari aspek konteks program kelas riset di MAN 2 Ponorogo sangat diperlukan untuk mendukung kebijakan Surat Keputusan Direktur Jenderal Pendidikan Islam Nomor 6757 Tahun 2020 tentang Penetapan Madrasah Penyelenggara Riset, guna menjamin tercapaianya visi, misi, dan tujuan madrasah dalam mengembangkan riset bagi warga madrasah, mewadahi bakat siswa di bidang riset, serta menjadi madrasah induk riset (sister school) bagi madrasahmadrasah yang berada dibawah naungan MAN 2 Ponorogo. Kedua, dilihat dari aspek input program kelas riset di MAN 2 Ponorogo telah menetapkan sistem seleksi untuk pendaftaran siswa kelas riset. Selain itu, penyediaan jumlah guru pembimbing riset dan sarana dan prasarana juga memadai untuk mendukung pelaksanaan program layanan kelas riset di MAN 2 Ponorogo. Ketiga, dilihat dari aspek proses 
program kelas riset di MAN 2 Ponorogo berjalan dengan lancar meski ada kendala yang menghambat kelancaraan program diantaranya: I) Guru mengalami hambatan dalam membimbing siswa untuk merumuskan masalah dan mengali ide terkait permasalahan yang ada di lingkungan sekitar mereka, 2)Siswa belum bisa memahami materi pelajaran riset karena pembelajaran dilakukan secara daring, sehingga siswa masih mengalami kesulitan untuk mencari masalah di lingkungan sekitar dan menemukan ide untuk pemecahan masalah, serta adanya rasa malas dalam diri siswa ketika hendak melakukan observasi lapangan dan mengerjakan tugas mata pelajaran riset.

Di samping, hambatan yang dihadapi ada faktor yang mendukung pelaksanaan program yaitu adanya keragaman permasalahan yang ada di lingkungan sekitar siswa, sehingga dapat memacu siswa untuk berpikir kritis dalam memberikan pemecahan masalah. Selain itu, adanya layanan bimbingan dari guru, dan penyediaan sarana dan prasarana juga menjadi faktor pendukung pelaksanaan program kelas riset di MAN 2 Ponorogo. Keempat,dilihat dari aspek produk pelaksanaan program kelas riset telah tercapai sesuai dengan kriteria ketercapaian, diantaranya: siswa dapat membuat karya ilmiah, siswa berpartisipasi dalam perlombaan di bidang riset dan mendapat juara, serta kemampuan siswa dapat ditunjukkan dengan rata-rata hasil belajar mata pelajaran riset berada pada kategori tuntas.

Merujuk pada kesimpulan yang telah dipaparkan, maka program kelas riset di MAN 2 Ponorogo perlu dilanjutkan dan ditingkatkan. Rekomendasi yang dapat diberikan agar pelaksanaan program kelas riset menjadi lebih baik dan dapat memberikan dampak positif terhadap pelaksanaan pembelajaran riset adalah adalah guru perlu menggunakan media pembelajaran online yang bervariasi dan metode mengajar yang menarik untuk meningkatkan minat belajar siswa. Selain itu, untuk meningkatkan kemampuan guru dan siswa dalam melakukan penelitian, maka pihak madrasah dapat bekerjasama dengan Lembaga Penelitian dan Pengabdian Masyarakat (LPMM) di universitas terdekat,untuk membekali mereka terkait teknis penelitian. Sehubungan dengan itu, untuk mengembangkan bakat di bidang riset, madrasah dapat mendorong siswa untuk mengikuti perlombaan riset di tingkat kabupaten, provinsi, nasional, maupun internasional dan pemberian hadiah apabila memenangkan perlombaan.

\section{Daftar Pustaka}

Abidah, A., Hidaayatullah, H. N., Simamora, R. M., Fehabutar, D., \& Mutakinati, L. (2020). The Impact of Covid-19 to Indonesian Education and Its Relation to the philosophy of "merdeka belajar". Studies in Philosophy of Science and Education, I(I): 38-49.

Alfianika, N. (2018). Metode Penelitian Pengajaran Bahasa Indonesia. Yogyakarta: Deepublish.

Ananda, R., \& Rafida, T. (20I7). Pengantar Evaluasi Program Pendidikan. Medan: Perdana Publishing.

Ekolu, S. O. (20I8). Relationship Between Research, Innovation and Development: A Review. Proceeding of the EAI International Conference for Research, Innovation and Development for Africa, 6 April 2018. Brussels, Belgium: ICST (Institute for Computes Sciences, Social-Informatics and Telecommunications Engineering).

Firdaus \& Zamzam, F. (2018). Aplikasi Metodologi Penelitian. Yogyakarta: Deepublish.

Firmadani, F. (2017). Pembelajaran Berbasis Riset Sebagai Inovasi Pembelajaran. Prosiding TEP \& PDs Transformation Pendidikan Abad 21, Mei 2017. Malang: Universitas Negeri Malang.

Haryati, S. (2020). Pengembangan Proses Belajar Peserta Didik dalam Meningkatkan Kualitas dan Profesionalitas Pengajar. Magelang: Pustaka Rumah CInta.

Indrawan, I. (20I5). Pengantar Manajemen Sarana dan Prasarana Sekolah. Yogyakarta: Deepublish.

Kementerian Riset, Teknologi, dan Pendidikan Tinggi. (2017). Rencana Induk Riset Nasional tahun 201 7-2045. Jakarta: Ristekdikti.

Kompri. (2017). Standarisasi Kompetensi Kepala Sekolah: Pendekatan Teori Untuk Praktik Profesional. Jakarta: Kencana.

Jumari \& Suwandi. (2020). Evaluasi Program Pendidikan Madrasah Tinjauan Teoretis dan Raktis Berbasis CIPP Model. Indramayu: Adanu Abimata.

Muryadi, A. D. (2017). Model Evaluasi Program dalam Penelitian Evaluasi. Jurnal IImiah PENJAS, $3(1): 1-16$.

Mutrofin. (20I4). Evaluasi Program Teks Pilihan Untuk Pemula. Yogyakarta: Laksbang Pressindo.

Naidoo, N. (20II). What is Research? A conceptual understanding. African Journal of Emergency Medicine, I: 47-48. 
Purnomo, P., \& Palupi, M. S. (2016). Pengetahuan Tes Hasil Belajar Matematika Materi Menyelesaikan Masalah yang Berkaitan dengan Waktu, Jarak dan Kecepatan Untuk Kelas V. Jurnal Penelitian (Edisi Khusus PGSD), 20(2): I5I157.

Padhi, G. (202I). Factor Affecting Teaching-Learning Process. International Journal of Creative Research Thoughts (IJCRT), 9(4): 2320-2882.

Seran, S. (2020). Metodologi Penelitian Ekonomi dan Sosial. Sleman: Deepublish.

Sima, V., Gheorghe, I. G., Subic, J., \& Nancu, D. (2020). Influences of the Industry 4.0 Revolution on the Human Capital Development and Consumer Behavior: A Systematic Review. Sustainability, 12(4035): I28.

Slameto. (20I5). Pembelajaran berbasis riset mewujudkan pembelajaran yang inspiratif. Satya Widya, 3 I (2), I02-II 3.

Sugiyono. (2018). Metode Penelitian Kuantitatif, Kualitatif, dan R\&D. Bandung: Alfabeta.

Sukmadinata, N. S. (20/3). Metode Penelitian Pendidikan. Bandung: Remaja Rosdakarya.
Suryani \& Hendryadi. (2016). Metode Riset Kuantitatif: Teori dan Aplikasi pada Penelitian Bidang Manajemen dan Ekonomi Islam. Jakarta: Prenadamedia Group.

Suzana, Y., \& Jayanto, I. (202I). Teori Belajar \& Pembelajaran. Malang: Literasi Nusantara.

Tuhurima, D. (2016). Evaluasi Program Akselerasi di SMP Negeri Kota Ambon. Kelola: Jurnal Manajemen Pendidikan, 3(I): I-I4.

Umar, M. K., Yusuf, M., Supartin, Uloli, R., Abjul, T., \& Ntobuo, N. E. (20I I). Pengembangan Pembelajaran Berbasis Riset di Program Studi Pendidikan Fisika FMIPA Universitas Negeri Gorontalo. Retrieved from https://repository.ung.ac.id.

Yulhendri, Syofyan, E., \& Afridona, S. (20/8). The Development of Research-Based Learning Model and Journal as for Graduate Students Scientific Publications of M.Pd. E on Economic. International Journal of Scientific and Research Publication, 8(5): 500-505.

Yusuf, M. (20I7). Asesmen dan Evaluasi Pendidikan: Pilar Penyedia Informasi dan Kegiatan Pengendalian Mutu Pendidikan. Jakarta: Kencana. 